\title{
The analysis of the factor that causes fraudulent financial reporting with fraud diamond
}

\author{
Ni Komang Astri Yulistyawati*, I Made Sadha Suardikha, I Putu Sudana \\ Faculty of Economics and Business, Udayana University, Bali, Indonesia \\ *Corresponding Author e-mail: komang.bali13@yahoo.co.id
}

\section{A R T I C LE I N F O}

Article history:

Available online

Keywords:

fraudulent financial reporting,

fraud diamond, manufacturing companies

DOI:

https://doi.org/10.20885/jaai.vol23. iss1.art1

\section{A B S T R A C T}

The purpose of this study is to obtain empirical evidence of the influence of the elements of fraud diamond namely: pressure, opportunity, rationalization, and capability on fraudulent financial reporting. The samples in the study were selected by usifigureng a non-probability sampling technique with a purposive sampling method with a total number of samples that met the sample selection criteria of 76 samples, namely 19 manufacturing companies during the four years of the 2011-2014 observation period. The collected data were analyzed by multiple linear regression analysis. Fraudulent financial reporting was measured using Dechow et al's F-Score (2007) which can be included as a first-pass test in evaluating the possibility of manipulation. This research showed that opportunity and rationalization are proven to be fraud diamond elements that most influence the occurrence of fraudulent financial reporting in the companies. While pressure and capability have no effect on fraudulent financial reporting. The implication of this study is that the ratio of total inventory as a proxy for opportunity measurement and the ratio of total accrual to total assets as a proxy for measurement of rationalization has a significant effect on fraudulent financial reporting, meaning that these ratios can be used by management to detect fraudulent financial reporting practices in manufacturing companies.

\section{Introduction}

Based on SAS No. 99 (AICPA, 2002) misstatements arising from fraudulent financial reporting are misstatements or intentional omissions of amounts or disclosures in financial statements to deceive users of financial statements. In the present, there have been many cases and practices related to fraud, not least in the process of preparing financial statements. Although accounting and financial reports are increasingly comprehensive and complex processes, there are still many gaps for certain parties to commit fraudulent financial statements. Healy and Wahlen (1999) revealed that in running a company, managers can use their knowledge of business and the opportunities they have to choose the method of reporting, estimation, and disclosure that is in accordance with the company's business economy, which has the potential to increase accounting value as a form of communication. However, the use of management ratings also creates opportunities for earnings management.

Many capital market players recognize the potential dangers in business, which are caused by fraudulent financial reporting. One of the fraudulent financial reporting cases that have occurred in the United States (US) involving a company's senior executives is a fraud case of HRC (HealthSouth Corp.) of USD 1.4 billion (Brooks \& Dunn, 2015). Thus, it is important for management to understand the impacts that can be generated from fraudulent financial reporting practices within the company so that early detection and prevention efforts can be made.

The researcher who first had the idea of a fraud triangle to investigate the cause of fraud was Cressey in his 1953 study entitled Other People's Money: A Study in the Social Psychology of Embezzlement (Cressey, 2953). The Fraud triangle has long been a useful tool for Certified Public Accountants in an effort to understand fraud risk. The Fraud triangle explains three factors that are present in each fraud situation, namely: 1) Pressure, which is the presence of incentives/ pressure/ need to commit fraud, 2) Opportunity, which is a situation that opens opportunities to enable fraud, and 3) Rationalization, which becomes an important element in the occurrence of fraud, where the perpetrator seeks justification for his actions.

According to Wolfe and Hermanson (2004), the nature and personal abilities of a person play a large role in allowing fraud to occur even though three fraud factors (pressure, opportunity and rationalization) support. Wolfe and Hermanson (2004) state that the possibility of fraud can be realized if the CEO of the company has technical skills to understand and utilize the weaknesses of existing internal controls. Thus, the ability of the CEO is a major factor in determining whether the weaknesses of internal control will ultimately lead to fraud. Wolfe and 
Hermanson (2004) believe that triangle fraud can be increased by considering the capability element to improve, prevent and detect fraud. These four elements are called fraud diamond.

Pardosi (2015) examined fraud diamond in detecting fraudulent financial statements. His research succeeded in proving that the nature of industry variable which is proxied by the ratio of total inventory and capability that is proxied by the change of directors of the company which has a positive and significant influence on the risk of fraudulent financial statements. Amaliah et al. (2015) conducted research on the perspective of fraud diamond theory in explaining non-GAAP (non-Generally Accepted Accounting Principles) earnings management. Her research found out that the capabilities proxied by changes in directors affect non-GAAP earnings management.

Based on the research background, the formulation of the problem in this study is whether the elements of fraud diamond (pressure, opportunity, rationalization, and capability) affect the fraudulent financial reporting. Therefore, the purpose of this study is to test the effectiveness of fraud diamond as an analytical tool in detecting and preventing fraudulent financial reporting. So that fraud diamond analysis can be useful to help find the causes of fraudulent behavior and provide solutions and efforts to eliminate these causes.

The results of this study can provide several benefits. First, this study can provide empirical evidence of the benefits of fraud diamond as an analytical tool in detecting and preventing fraudulent financial reporting. Second, this research can help prospective investors in the analysis of the company's financial statements to determine the performance of management who will manage their investment funds and avoid investing in companies indicated to commit fraudulent financial reporting to avoid investment losses. Third, this research can be an important consideration for companies in making and developing policies to improve internal control and supervision as an effort to prevent and detect fraudulent financial reporting.

\section{Literature Review}

\section{Agency Theory}

Agency relations are defined as one or more people (principals) involved by other people (agents) to do some services on their behalf which involves delegating some authority for decision making to the agent. The foundation of agency theory is assuming that the interests of principals and agents are different (Jensen \& Meckling, 1976). According to Ujiyantho and Pramuka (2007) in a company, managers act as agents who are morally responsible for optimizing the profits of the owners (principals), but on the other hand managers also have an interest in maximizing their welfare. Problems can occur when executives or managers in making decisions prioritize their personal benefits (Rationalization). Conflict of interest between agents and principals result in managers as agents facing various pressures from principals to find ways to increase company performance.

The main concern of agency theory as proposed by Jensen and Meckling (1976) is how to compile the best contract between the agent and principal in measuring the performance of the agent with regard to receiving incentives so that the agent acts in the interest of the principal. The gateway to fraud will be more open if management has broad authority (Capability) as well as opportunities and chances to increase profits (Opportunity). The solution to one of the agent's problems is to ensure that executives or managers act in the best interests of the owner by increasing the amount and quality of information available to principals and making senior executives become owners of parts of the company through their compensation packages.

\section{Fraud}

According to Singleton et al. (2006), fraud has many definitions, fraud is a generic term, and includes all the various ways that humans can use with their ingenuity, which is forced by one individual, to gain more benefits from other individuals. Fraud, which includes fraud, cunning, and unfair ways in which other individuals are cheated.

SAS No. 99 defines Fraud as a deliberate action that results in material misstatement in the financial statements that are the subject of an audit (AICPA, 2002). Three conditions are generally present when fraud occurs. First, management or other employees have incentives or are under pressure, which provides a reason for fraud. Second, the situation exists - for example, the absence of control, ineffective control, or management's ability to override controls that provide opportunities for fraud to be committed. And third, those involved can rationalize the motive for committing fraud. The greater the incentive or pressure, the more likely an individual will be to rationalize acceptability in committing fraud.

ACFE (2012) divides fraud in 3 (three) types or typologies based on the actions committed, that are:

1) Asset misappropriation, including abuse/ theft of assets or belongings of the company or other parties. This is a form of fraud that is most easily detected because it is tangible or measurable (defined value).

2) Fraudulent statements, covering actions carried out by company executives or government agencies to cover up actual financial conditions by conducting financial manipulation in the presentation of their financial statements for profit. 
3) Corruption, this type of fraud often cannot be detected because the parties working together enjoy shared benefits. These include abuse of authority/ conflict of interest, bribery, illegal acceptance, and economic extortion.

\section{Fraud Diamond}

There are various forms of fraud in accounting. In general, fraud will always occur, if there are no detection and prevention efforts. There are several efforts and perspectives in reviewing and detecting fraud, one of which is the perspective of fraud diamond which was first coined by Wolfe and Hermanson (2004). The elements of fraud diamond theory include:

1) Pressure, namely the existence of incentives / pressure / need to commit fraud.

2) Opportunity, which is a situation that opens opportunities to enable fraud.

3) Rationalization, which is an attitude or character that causes individuals to rationally commit fraud that enables them to consciously and intentionally commit dishonest actions.

4) Capability, is the ability of individuals who play a major role regarding whether fraud can actually occur. One must have the ability to see the gap to commit fraud as an opportunity and to take advantage continuously.

\section{Fraudulent Financial Reporting}

Based on SAS No. 99 (AICPA, 2002), there are two types of relevant misstatements for the auditor's judgment in assessing frauds that arise from fraudulent financial reporting and misstatements arising from asset misappropriation. Misstatements arising from fraudulent financial reporting are intentional misstatements or omissions on amounts or disclosures in financial statements designed to deceive users of financial statements whose effects cause financial statements, in all material matters, not to be presented in accordance with applicable accounting principles general (GAAP). Types of fraudulent financial reporting include: 1) Manipulation, forgery, or changes to accounting records or supporting documents relating to the financial statements prepared. 2) Intentional misrepresentations or omissions concerning events, transactions, or other important information in the financial statements. 3) Deliberately misusing accounting principles related to the amount, classification, method of presentation, or disclosure in financial statements.

Misstatements arising from asset misappropriation (asset misuse) involve the theft of assets belonging to an entity where the effect of theft causes the financial statements, in all cases which are in all material respects, not to be presented in accordance with generally accepted accounting principles. Abuse of assets can be done in various ways, including embezzlement, asset theft, or intentionally causing the entity to pay for goods or services that have not been received.

\section{The Effect of Pressure on Fraudulent Financial Reporting}

Based on SAS No. 99 (AICPA, 2002), one of the conditions that causes fraud in financial statements is pressure. Pressure can occur when management is in need of money to meet personal needs such as pressure for medical expenses, pressure from the family that demands economic success, and a luxurious lifestyle (Rustendi, 2009). Management pressure to meet his personal financial needs can be a trigger for fraud by increasing company profits. Based on the agency theory proposed by Jensen and Meckling (1976), principals and agents have different objectives. Principal wants a high return on his investment, while the agent wants to get great compensation for his work. These differences lead to agency conflicts, namely conflicts of interest between managers and shareholders. Based on the description, the hypothesis proposed is as follows:

H1: Pressure has a positive effect on fraudulent financial reporting

\section{The Effect of Opportunity on Fraudulent Financial Reporting}

One of the causes of fraudulent financial reporting is due to factor opportunities. According to Gagola (2011), opportunity will arise because of a weak internal control system. Companies with weak internal controls will have many gaps that make it an opportunity for management to manipulate financial transactions. Summers and Sweeney (1998) argue that accounts receivable and inventory require a subjective assessment in estimating uncollectible accounts and obsolete inventory. Summers and Sweeney (1998) state that because of the subjective judgment in determining the value of the account, management can use the account as a tool for financial report manipulation. Based on the description, the hypothesis proposed is as follows:

$\mathrm{H} 2$ : Opportunity has a positive effect on fraudulent financial reporting 


\section{The Effect of Rationalization on Fraudulent Financial Reporting}

Rationalization is an action taken by perpetrators of fraud to seek justification for his actions. Rationalization is a reason (personal or because there are other factors) that can justify an act even if it is actually wrong. Attitudes or characters that cause one or more individuals to rationally commit fraud that allows them to consciously and intentionally commit dishonest actions. Rationalization is full of subjective judgments chosen by company management. According to Skousen et al. (2009), assessment and management decision making related to the use of accrual principles will be reflected in the value of corporate accruals. Beneish (1999) estimates higher positive accruals (less cash) associated with the possibility of higher income manipulation. Based on the description, the hypothesis proposed is as follows:

H3: Rationalization has a positive effect on fraudulent financial reporting

\section{The Effect of Capability on Fraudulent Financial Reporting}

In fraud diamond theory owned by Wolfe and Hermanson (2004), capability is how much power and capacity of a person to commit fraud in the company environment. According to Wolfe and Hermanson (2004), several major cases related to fraud will not occur without a person with the capability to do so in a position or position that allows him to commit fraud within the company. Wolfe and Hermanson (2004) state that fraud perpetrators are people who are smart enough and understand the weaknesses of the company's internal control, and that the person uses the position, function, or authority they have to make a profit. Wolfe and Hermanson (2004) concluded that changes in directors could indicate fraud. According to (Wolfe \& Hermanson, 2004), the change of directors can be an attempt by the company to improve the performance of previous directors by making changes to the composition of the board of directors or the recruitment of new directors who are considered more competent than the previous directors. Based on the description, the hypothesis proposed is as follows:

H4: Capability has a positive effect on fraudulent financial reporting

\section{Research Method}

The research was conducted at PT. Indonesia Stock Exchange (IDX). The data in this study was obtained by accessing the official website of the Indonesia Stock Exchange, www.idx.co.id. The object of this study is nonfinancial companies engaged in the manufacturing sector which are listed on the Indonesia Stock Exchange during 2011- 2014.

The type of data used in this study is quantitative data in the form of company financial statements that have been published on the official website of the Indonesia Stock Exchange. While the data source is secondary data, namely the Annual Financial Report of manufacturing companies listed on the Indonesia Stock Exchange obtained from the Indonesia Stock Exchange (IDX) through direct search of the Indonesia Stock Exchange's official website, www.idx.co.id, from accounting journals published, and from previous researches.

\section{Fraudulent Financial Reporting $(\mathrm{Y})$}

The dependent variable in this study is fraudulent financial reporting which is proxied by the F-Score as determined by Dechow et al. (2011). F-Score is used to measure fraudulent financial reporting seen from accrual quality (accrual quality) and financial performance (financial performance). Accrual quality is calculated by RSST accruals, namely accrual calculations belonging to Richardson et al. (2006), while financial performance is measured based on measurements belonging to Skousen et al. (2009). Measurements used in calculating financial performance are change in receivable, change in inventory, change in cash sales, and change in earnings.

Accrual calculations belonging to Richardson et al. (2006), defines all non-cash and non-equity changes in a company's balance sheet as accruals and distinguishes the characteristics of reliability working capital accruals, non-current operating accruals, and financing accruals and components of assets and liabilities on accrual types. This classification is considered good for explaining both the short-term (in the coming year) and long-term effects of future earnings accruals, given that there are various and long-term impacts ranging from company operations, investment and funding to future performance.

Whereas in measuring financial performance, Dechow et al. (2011) suggested that the manipulations made with changes in receivable accounts could have an impact on increasing sales growth. Manipulation carried out with changes to inventory accounts can have an impact on increasing gross margins. Measurement of changes in cash sales is used to evaluate whether sales that are not subject to accrual management are declining. Changes in earnings were also analyzed because managers seemed to prefer to show positive earnings growth. During the period of manipulation, managers tend to use accruals to show a positive increase in profits. 


\section{Pressure (X1)}

Pressure (pressure) is a condition because there is an incentive / pressure / need for managers or employees to commit fraud. According to Sulityani (2010), managers are expected to increase the value of the company through increasing the prosperity of the owners or shareholders. However, managers often have other goals that are contrary to the main objective, which is usually used for self-interest. Pressure in this study is proxied by the percentage of share ownership in companies owned by insiders, namely by calculating shares held by management divided by outstanding common shares.

\section{Opportunity (X2)}

Opportunity is a situation that opens opportunities to allow for fraud. Summers and Sweeney (1998) examined accounts receivable and inventory. Summers and Sweeney (1998) argue that accounts receivable and inventory require subjective valuation in estimating uncollectible accounts and obsolete inventories. Therefore, management can use these accounts as a tool for financial report manipulation. Opportunity in this study is proxied by the ratio of total inventories, namely by dividing inventories this year with sales this year minus the division of inventories with sales in the previous year.

\section{Rationalization (X3)}

Rationalization is an attitude or character that causes one or more individuals to rationally commit fraud that enables them to consciously and intentionally commit dishonest acts. Rationalization is full of subjective judgments of the company. In this study, rationalization is proxied by Beneish (1999) Total Accrual to Total Asset ratio. Beneish (1999) uses the Total Accrual to Total Asset ratio to estimate the extent to which cash underlies reported income. According to Beneish (1999) total accruals will affect the fraudulent financial reporting. This opinion is supported by Skousen et al. (2009) which states that total accrual ratios can be used to describe rationalization related to the use of accrual principles by management.

\section{Capability (X4)}

According to Wolfe and Hermanson (2004), capability is how much power and capacity of a person to commit fraud in a company environment. Capability or individual abilities play a major role in whether fraud can actually occur. Capability in this study is proxied by the change of company directors. Wolfe and Hermanson (2004), state that changes in directors can be a company effort to improve the performance of previous directors by making changes to the composition of the board of directors or the recruitment of new directors who are considered more competent than the previous directors. Capability is measured using a dummy variable, that is, companies that make board changes during the 2011-2014 period will be given a value of 1, whereas if there is no change in the company's directors during the 2011-2014 period, it will be given a value of 0 .

\section{Population and Samples}

The population in this study were non-financial companies engaged in the manufacturing sector listed on the Indonesia Stock Exchange (IDX) for the period 2011-2014. While the samples in the study were selected using nonprobability sampling techniques with purposive sampling method, with the following criteria:

1) Manufacturing companies listed on the Indonesia Stock Exchange during the period 2011-2014 respectively.

2) Manufacturing companies that publish annual financial reports on the company's website or IDX website during the period 2011-2014 which are expressed in rupiahs (Rp.).

3) Annual financial reports that have data relating to research variables (overall data available in publications during the 2011-2014 period).

4) Manufacturing companies that are not delisted from the IDX during the observation period (2011-2014).

5) Manufacturing companies that have insider ownership during the 2011-2014 period.

Based on data obtained from the official website of the Indonesia Stock Exchange, www.idx.co.id, there are 106 manufacturing companies registered in succession during the 2011-2014 observation period. However, from the total sample there were only 19 manufacturing companies that met all the criteria for determining the research sample. The study period was four years of observation (2011-2014) so that the total sample used in this study amounted to 76 samples.

The data analysis technique used to test the hypothesis in this study is multiple linear regression analysis using the regression equation as follows: 
$Y=\alpha+\beta_{1} X_{1}+\beta_{2} X_{2}+\beta_{3} X_{3}+\beta_{4} X_{4}+e$

Note:

$\begin{array}{ll}\mathrm{Y} & =\mathrm{F}-\text { Score } \\ \alpha & =\text { Constant }\end{array}$

$\beta 1, \beta 2, \beta 3, \beta 4=$ Regression coefficient

$\mathrm{X} 1=$ Pressure

X2 $\quad=$ Opportunity

X3 $\quad=$ Rationalization

X4 $\quad$ Capability

e $\quad$ error

\section{Results and Discussion}

\section{Description of Research Samples}

Table 1 shows the descriptive statistical analysis that gives a description or description of the characteristics of the research variables seen from the minimum, maximum, average (mean), and standard deviation values. The table contains descriptive statistics of the dependent variable namely fraudulent financial reporting and independent variables, namely pressure, opportunity, rationalization, and capability used in this study.

Table 1. Descriptive Statistics

\begin{tabular}{|c|c|c|c|c|c|}
\hline Variable & $\mathrm{N}$ & Minimum & Maximum & Mean & $\begin{array}{c}\text { Std. } \\
\text { Deviation }\end{array}$ \\
\hline Pressure (X1) & 76 & 0.00 & 0.7719 & 0.1257 & 0.2265 \\
\hline Opportunity (X2) & 76 & -0.2675 & 0.4076 & 0.0034 & 0.0785 \\
\hline Rationalization (X3) & 76 & -0.4941 & 0.5389 & -0.0446 & 0.1479 \\
\hline Capability (X4) & 76 & 0.00 & 1.00 & 0.3289 & 0.4729 \\
\hline Fraudulent Financial Reporting $(\mathrm{Y})$ & 76 & -1.4949 & 1.7289 & 0.0058 & 0.4395 \\
\hline Valid N Listwise & 76 & & & & \\
\hline
\end{tabular}

Source: SPSS analysis result, 2016

The results of the descriptive statistical analysis of the Pressure variable, which is proxied by the cumulative percentage of share ownership by insiders, show that the average level of share ownership by insiders in the sample companies is $12.57 \%$ with ownership ranges from $0 \%$ to $77.19 \%$.

The results of the descriptive statistical analysis of the Opportunity variable which is proxied by the total inventory ratio show that the sample companies have an average total inventory ratio of $0.034 \%$. The minimum value of the total inventory ratio shows a negative value which indicates that there is a sample company that manages its inventory less optimally. Summers and Sweeney (1998) argue that accounts receivable and inventory require a subjective valuation in estimating uncollectible accounts and obsolete inventories so that less optimal inventory management can open opportunities for actors to carry out assets misappropriation.

The results of the descriptive statistical analysis of the Rationalization variable which is proxied by the Total Accrual to Total Asset ratio indicate that the sample company has an average Total Accrual to Total Asset ratio of $-4.46 \%$ which indicates the small amount of cash underlying the company's reported income. Beneish (1999) estimates higher positive accruals (less cash) associated with the possibility of higher income manipulation.

The results of the descriptive statistical analysis of the Capability variable, which is proxied by the change in the board of directors of the company, show that the sample companies that made the change of board of directors were $32.89 \%$ of the total samples studied.

Based on the results of SPSS output, the determination coefficient value of this study is indicated by the value of R Square of 0.121 which means that $12.1 \%$ of pressure, opportunity, rationalization and capability can influence fraudulent financial reporting indications in the company while $87.9 \%$ are influenced by other variables which was not used in this study. ANOVA test or F Test shows F value of 2,437 with a significance level of 0.05 . This means that simultaneously the independent variables in this study, namely pressure, opportunity, rationalization, and capability have a significant influence on the dependent variable, namely fraudulent financial reporting. 
While testing of the hypotheses carried out in this study is to do the $t$ test. Testing is done using a significant level of 0.05. If the independent variable has a level of significant 50.05 then $\mathrm{H} 0$ is rejected. But if the independent variable has a significant level $>0.05$ then $\mathrm{H} 0$ is accepted. The hypothesis test results are shown in Table 2.

Table 2. Hypothesis Test Results

\begin{tabular}{lcc}
\hline \multicolumn{1}{c}{ Variable } & $t$ & Sig. \\
\hline Pressure $(X 1)$ & 0.259 & 0.79 \\
Opportunity (X2) & 1.980 & $0.05^{*}$ \\
Rationalization (X3) & 2.159 & $0.03^{*}$ \\
Capability (X4) & -0.160 & 0.87 \\
\hline Nope
\end{tabular}

Note: *) Significant

Source: SPSS analysis result, 2016

Based on the results of testing the first hypothesis ( $\mathrm{H} 1)$ it can be concluded that the pressure proxied by the percentage of share ownership by insiders does not have a positive effect on fraudulent financial reporting. This means that the first hypothesis is rejected. The results of this study are in line with the results of research conducted by Norbarani (2012) which shows that the pressure proxied by the ratio of share ownership by insiders does not significantly influence fraudulent financial reporting. However, this study is not in line with the research belonging to the study of Skousen et al. (2009) which states that share ownership by the board of commissioners and board of directors affects fraudulent financial reporting. The results of this study can be explained by the agency theory approach. Pressure arises because of the desire of company executives to get large compensation for their work. Based on agency theory, making senior executives become owners of parts of the company through compensation packages is one way to bridge the conflict between the agent and the principal. By making senior executives become owners of parts of the company, they will work to improve the financial performance of the entity. So, when the company has good financial performance, it will also benefit senior executives because the financial condition of the entity will also affect their financial condition as the owner of a part of the company.

Based on the results of testing the second hypothesis (H2) it can be concluded that the opportunity proxied by the ratio of total inventory has a positive effect on fraudulent financial reporting. This means that the second hypothesis is accepted. The findings of this study support the theory of fraud used in this study as proposed by ACFE (2012) that asset misappropriation is one of the fraud typologies. If the amount of inventory stored is too much, then this will reduce solvency because the funds used to increase inventory should be able to divert its use for expansion or for company operations, can increase storage costs, warehouse rental costs, and insurance costs. Risk of loss due to price reduction or because damage to goods will also increase. The results of this study are in line with the results of research obtained by Pardosi (2015) which states that the opportunity proxied by the ratio of total inventory has a significant effect on the fraudulent financial reporting. So that it can be concluded that opportunity is the main variable that drives the occurrence of fraudulent financial reporting.

Based on the results of testing the third hypothesis $(\mathrm{H} 3)$ it can be concluded that the rationalization represented by the ratio of total accrual to total assets has a positive effect on fraudulent financial reporting. This means that the third hypothesis is accepted. The findings of this research support the diamond fraud theory used in this study which states that rationalization as one element of diamond fraud is an important element in the occurrence of fraud. According to Beneish (1999), total accruals will affect fraudulent financial reporting because accruals are strongly influenced by management decisions in rationalizing financial statements. The argument is also supported by Marinakis (2011) who argues that earnings management through accruals is a process in which a manager can increase or decrease the accrual level of accounting (such as accounts receivable, inventory, debt, deferred income, accrued liabilities, and prepaid expenses) to achieve the desired level of profit. The results of this study are consistent with the results of studies obtained by Vermeer (2003) and Sihombing and Rahardjo (2014) which state that the rationalization proxied by the ratio of total accrual to total assets has a significant effect on fraudulent financial reporting. But the results of this study conflict with proprietary research Skousen et al. (2009) which states that total accrual ratios do not significantly influence financial statement fraud.

Based on the results of testing the fourth hypothesis $(\mathrm{H} 4)$ it can be concluded that the capability represented by the change of company directors has no positive effect on fraudulent financial reporting. This means that the fourth hypothesis is rejected. The findings in this study cannot prove that capability is the cause of fraudulent financial reporting. This is most likely due to the change of the board of directors in the manufacturing company as the research sample is the replacement of the routine board of directors where the new board members come from the internal company. After the change of the board of directors, some members of the old board of directors get new positions in the company as members of the board of commissioners. According to Wells (2002) the reason for routine changes in the board of directors is suspected because the principle wants a refresher on the 
structure of the board of directors. The findings of this study do not support the diamond fraud theory used in this study. According to Wolfe and Hermanson (2004) the nature and personal abilities of a person who plays a large role to enable fraud can occur, capability is needed to find out how much power and capacity a person has committed fraud in the company environment. The results of this study are consistent with the research conducted by Sihombing and Rahardjo (2014) which states that capability proxied by changes in the board of directors does not affect the fraudulent financial reporting. But the results of this study contradict the research of Skousen et al. (2009) who succeeded in proving that the change of directors has a positive effect on fraudulent financial statements and Pardosi (2015)which states that changes in the board of directors have a significant influence on fraudulent financial reporting.

\section{Conclusion}

Based on the results of data analysis and discussion, it can be concluded as follows: First, pressure does not affect the fraudulent financial reporting. This indicates that share ownership by insiders does not necessarily trigger management or senior executives to commit fraudulent financial reporting. Second, opportunity influences the fraudulent financial reporting. This finding indicates that the greater the opportunity for management to commit fraud, the greater the risk of fraudulent financial reporting in the company. In this study, the opportunities created by the weak control of inventory management are the main causes for perpetrators to commit fraudulent financial reporting. Third, rationalization has an effect on the fraudulent financial reporting. This finding indicates that management rationalization is an important element in the occurrence of fraudulent financial reporting in companies. Rationalization of management in the subjective assessment and decision making of companies related to the use of accrual principles is proven to increase management risk in conducting fraudulent financial reporting. Fourth, capability does not affect the fraudulent financial reporting. This indicates that the replacement of the company's board of directors is not the main indication that fraudulent financial reporting has occurred in the company. This can be caused by the change of the board of directors in the sample company is a routine change, in which the new board members come from the internal company. So the reason for the change of the board of directors is not because the old board of directors had a poor performance, but because of the role of position within the structure of the board of directors.

\section{Implications of Research Findings}

Based on the findings obtained in this study, the implication of this finding is pressure proxied by the ratio of share ownership by insiders is proven to have no significant effect on fraudulent financial reporting, so investors and prospective investors should not need to be afraid of the existence of insider ownership in manufacturing companies where investors invest their capital. Making a senior executive as the owner of a company part through a compensation package can bridge the conflict between the agent and the principal. When a company has good financial performance, it will also benefit senior executives because the financial condition of the entity will affect their financial condition as the owner of a part of the company.

Opportunity proxied by the ratio of total inventory proved to have a significant effect on fraudulent financial reporting, so it can be concluded that opportunity is the main trigger for increasing fraudulent financial reporting in manufacturing companies. The results of this study indicate that opportunity is created due to weak control of inventory management, so that it can open fraudulent financial reporting opportunities that can occur in manufacturing companies.

Rationalization proxied by the ratio of total accrual to total assets proved to have a significant effect on fraudulent financial reporting, so it can be concluded that rationalization is the main trigger for the increase in fraudulent financial reporting in manufacturing companies. Management rationalization related to accrual policies chosen by management will be reflected in the value of corporate accruals. The results of this study indicate the amount of cash underlying income reported in manufacturing companies is relatively small. Beneish (1999) estimates higher positive accruals (less cash) associated with the possibility of higher income manipulation.

Capability proxied by changes in the board of directors does not affect fraudulent financial reporting, so that the change of the board of directors occurs regularly not because the old board of directors has a poor performance, but as an effort to refresh the board structure.

\section{Research Limitations and Suggestions}

This study has several limitations, namely First, researchers only use non-financial companies engaged in the manufacturing sector listed on the Indonesia Stock Exchange for the 2011-2014 period as research samples, so that the results of the study cannot be generalized to other sector companies. Second, researchers use the board of 
directors as a proxy for capability measurement in this study. After the data analysis test process is carried out, the change in the board of directors that occurs in the sample company is only a change in the board of directors that occurs routinely.

Based on these limitations, the advice that can be given to the next researcher is, First, researchers can then consider using non-routine board of directors as a proxy for measuring capability. Second, for future researchers who are interested in conducting similar research or who want to develop this research, they can consider different data analysis techniques and measurement proxies, such as using logistic regression analysis, using Jones's modified model as a proxy for fraudulent financial reporting, and other measurement proxies which can be used in further research.

\section{References}

Amaliah, B. N., Januarsi, Y., \& Ibrani, E. Y. (2015). Perspektif fraud diamond theory dalam menjelaskan earnings management Non-GAAP pada perusahaan terpublikasi di Indonesia. Jurnal Akuntansi \& Auditing Indonesia, 19(1), 51-67.

American Institute of Certified Public Accountant (AICPA). (2002). Report to The Nations on Occupational Fraud and Abuse. New York.

Association of Certified Fraud Examiners (ACFE). (2012). Report to The Nations on Occupational Fraud and Abuse. Austin.

Beneish, M. D. (1999). The detection of earnings manipulation. Financial Analysts Journal, 55(5), 24-36.

Brooks, L. J., \& Dunn, P. (2015). Business \& Professional Ethics ( $7^{\text {th }}$ Edition). Ohio: South-Western College.

Cressey, D. R. (1953). Other people's money: a study of the social psychology of embezzlement. New York: Free press.

Dechow, P. M., Ge, W., Larson, C. R., \& Sloan, R. G. (2011). Predicting material accounting misstatements. Contemporary Accounting Research, 28(1), 17-82.

Gagola, A. S. C. (2011). Analisis faktor risiko yang mempengaruhi kecenderungan kecurangan pelaporan keuangan perusahaan publik di Indonesia. Universitas Diponegoro.

Healy, P. M., \& Wahlen, J. M. (1999). A review of the earnings management literature and its implications for standard setting. Accounting Horizons, 13(4), 365-383.

Jensen, M. C., \& Meckling, W. H. (1976). Theory of the firm: Management behavior, agency costs and ownership structure. Journal of Financial Economics, 3(1976), 305-360. https://doi.org/10.1016/0304405X(76)90026-X

Marinakis, P. (2011). An investigation of earnings management and earnings manipulation in the UK. University of Nottingham.

Norbarani, L. (2012). Pendeteksian kecurangan laporan keuangan dengan analisis fraud triangle yang diadopsi dalam SAS no. 99. Universitas Diponegoro.

Pardosi, R. W. (2015). Analisis fraud diamond dalam mendeteksi kecurangan laporan keuangan pada perusahaan manufaktur di Indonesia dengan menggunakan fraud score model (tahun 2010-2013). Universitas Lampung.

Richardson, S. A., Sloan, R. G., Soliman, M. T., \& Tuna, I. (2006). The implications of firm growth and accounting distortions for accruals and profitability. The Accounting Review, 81(3), 713-743.

Rustendi, T. (2009). Analisis terhadap faktor pemicu terjadinya fraud : suatu kajian teoritis bagi kepentingan audit internal. Jurnal Akuntansi, 4(2), 705-714.

Sihombing, K. S., \& Rahardjo, S. N. (2014). Analisis fraud diamond dalam mendeteksi financial statement fraud (studi empiris pada perusahaan LQ-45 yang terdaftar di Bursa Efek Indonesia tahun 2010-2012). Diponegoro Journal of Accounting, 3(2), 1-12.

Singleton Singleton, T. W., Singleton, A. J., Bologna, G. J., \& Lindquist, R. J. (2006). Fraud Auditing and Forensic Accounting ( $3^{\text {rd }}$ Edition). Hoboken, N.J: John Wiley \& Sons, Inc. 
Skousen, C. J., Smith, K. R., \& Wright, C. J. (2009). Detecting and predicting financial statement fraud: The effectiveness of the fraud triangle and SAS No. 99. Corporate Governance and Firms Performance, 13, 23-81.

Sulityani, N. (2010). Pengaruh kepemilikan manajerial, kepemilikan institusional, kebijakan dividen, dan leverage terhadap nilai perusahaan di Jakarta Islamic Index tahun 2004-2008. Universitas Sunan Kalijaga.

Summers, S. L., \& Sweeney, J. T. (1998). Fraudulently misstated financial statements and insider trading: An empirical analysis. The Accounting Review, 73(1), 131-146.

Ujiyantho, M. A., \& Pramuka, B. A. (2007). Mekanisme corporate governance, manajemen laba dan kinerja keuangan (studi pada perusahaan go publik sektor manufaktur). Simposium Nasional Akuntansi (SNA) Ke X, 1-26. Makasar: Ikatan Akuntan Indonesia Kompartemen Akuntan Pendidik (IAI KAPd).

Vermeer, T. (2003). The impact of SAS no. 82 on an auditor's tolerance of earnings management. Journal of Forensic Accounting, 5, 21-34.

Wells, P. (2002). Earnings management surrounding CEO changes. Accounting and Finance, 42(2), $169-193$.

Wolfe, D. T., \& Hermanson, D. R. (2004). The fraud diamond: Considering the four elements of fraud. CPA Journal, 74(12), 38-42. 